\title{
Editor's Introduction: George Grant's Nietzsche
}

A few months before Grant's last illness, I sent him a copy of a work by Jacques Derrida. He knew the influential French deconstructionist by reputation, but had never read any of his books. Derrida's extensive influence throughout Europe and America was evidence of the spread of Nietzsche's influence and that of his epigones. Indeed most of those who had listened to the original broadcasts of 'Time as History' and most who read the lectures in their printed form, Grant believed, were unconscious Nietzscheans, although they had probably imbibed their Nietzsche through writers such as Derrida or Freud or Max Weber, rather than directly. Nietzsche was in the intellectual air we breathed, and his thought determined ours all the more effectively because we had not thought through, as Nietzsche had (with what Grant always called 'consummate clarity'), the implications of his novel vision of human beings and human life. As moderns, especially as modem North Americans, we simply take for granted that time is history and we live our lives beyond good and evil (that is, oblivious of eternity), unaware of the moral abyss into which we are falling. 


\section{A Family History of a Family of Historians}

When George Grant died in Halifax in 1988 his obituarists remembered him as the celebrated author of Lament for a Nation (1965) and Technology and Empire (1969). He was, in their view, a Canadian nationalist, a fierce critic of modern technology and the country's most famous political philosopher. No one, it seems, remembered that Grant had started his intellectual life as an historian or that his transmutation into a philosopher took place slowly over several decades.

Yet he had come by his original interest in history quite naturally: it was one branch of the family business (education and politics were the others). His maternal grandfather, Sir George Parkin (1846-1922), was the author of a biography of Sir John A. Macdonald. George Monro Grant, his paternal grandfather and the celebrated principal of Queen's University, had published Ocean to Ocean (1873), the diary of the joumey across Canada he made with Sir Sandford Fleming. Towards the end of his life G.M. Grant also published French Canadian Life and Character, with historical and descriptive sketches of the scenery and life in Quebec (1899).

William Grant, George Grant's father, was the most distinguished historian of the family. Trained in history at Queen's University, he went to Oxford to study Greats (classics). From 1906 until 1910 he lectured in colonial history at Oxford; then he returned to teach history at Queen's. Among his publications were a biography of his father (1905), a controversial history of Canada for use in Ontario high schools (1914) and The Tribune of Nova Scotia: A Chronicle of Joseph Howe (1915). William Grant also volunteered for active service in the Kaiser's war and saw action in France, where he was seriously injured. This experience profoundly affected his son: 'My father was a Nova Scotian, who had grown up in Kingston, Ontario, and was essentially a very gentle, strong scholar, who I think, above all, was ruined by the First World War. He was ruined physi- 
cally; he was terribly wounded. For these people, who had grown up in the great era of progress, to meet the holocaust of the trenches was terrible."

The First World War, perhaps even more than the Second, was the great historical event that most influenced Grant, even though he was bom on 13 November 1918, two days after the armistice. From his own experiences in France William Grant had become very bitter about the useless slaughter of the war, and his interest in the new League of Nations in the 1920s and 30s reflected his desire to prevent the recurrence of such a tragedy. His son's opinions on international affairs while a student at Upper Canada College, and later at Queen's University, closely reflected his father's views.

At Queen's, Grant also followed in his father's footsteps, and chose history as his major subject. However, even as an undergraduate, he was drawn to grand themes, rather than to the minutiae of historical research. As he complained to his mother: 'Professor Trotter has set us a colossal essay that does not have to be in till February although the bibliography has to be in next week. We each handed in three subjects and he chose which was best. My preference was "The Colonial Policy of the Protectorate." I am going to do that one. He says it is too extensive and I will have to narrow down the field to such a topic as "Cromwell's policy in the West Indies." That kind of detailed history gets me down.'2

After he completed his studies at Queen's (and won the history medal), he headed for Oxford on a Rhodes scholarship to study law. He found his new subject exciting for the intellectual discipline it imposed, but tiresome because of its attention to detail and its indifference to broader questions. 'Law is incredibly complicated and as yet my rather feeble mind cannot face it. In some ways it is disappointing because it is merely stating the law never asking what it is (as the basis) never asking why it is, as it is, never asking what it ought to be. ${ }^{3}$ The excitement he found in the grander themes of philo- 


\section{x Editor's Introduction}

sophical history are clear in his reaction to meeting the English historian Amold Toynbee. "Toynbee is the colossal kind of person who makes one feel that even if civilization goes down now it is merely temporary as there is something essentially a part of God in man's make up.'4

After service as an Air Raid Precautions warden during the German bombing of London, Grant returned home in February 1942 suffering from a nervous breakdown and tuberculosis. He spent most of the next year recovering in bed. In 1943 he published a pamphlet, Canada - An Introduction to a Nation. In 1945 he addressed the same theme in The Empire, Yes or No? When he returned to Oxford after the war he decided to study theology, but he earned a little extra money by writing historical articles on Canada for Chambers's Encyclopedia. As he later explained to a student group: '... before I became a philosopher I studied history and still think very much as an historian."s

The type of history to which he was increasingly drawn, however, reflected his early predispositions to the philosophy of history. This disposition was intensified by the study he made of philosophy after he was appointed to teach that subject in 1947 at Dalhousie University in Halifax, Nova Scotia. This concern is clear in his CBC radio address in praise of Charles Cochrane and his great work, Christianity and Classical Culture. 'Amold Toynbee' he said, 'has just completed his mammoth Study of History. Rheinhold Niebuhr has written his Nature and Destiny of Man. But in Toynbee there is always a fuzziness about philosophic questions - a failure to analyse deeply. In Niebuhr there is a lack of subtlety - his answers are decisive but too easy. Beside either of them Cochrane is like a clear deep river, winding certainly to the sea. He goes right to the heart of the matter.' 6

Grant himself tried to go right to the heart of the matter in his first major publication, Philosophy in the Mass Age (1959). In it he contrasted the Platonic view of time as the moving 


\section{Editor's Introduction $\mathbf{x i}$}

image of eternity with a rival understanding, which he called 'time as history': 'This view of time as history was brought out from the narrow confines of the Jewish people into the main stream of westem civilization by Christianity. This is what the doctrine of the Trinity is: it incorporates into the timeless God of the Greeks, the God of project and of suffering; that is, the God of love. The sense of the unique importance of historical events was made absolute by the Incarnation. Our redemption has been achieved once and for all in His passion and death. This was not going to be repeated an infinite number of times. It was a unique and irreversible event."7

Throughout the 1950s, Grant was deeply engaged with the thinker who had brought the concept of time as history into Westem thought, G.W.F. Hegel. ${ }^{8}$ He had hitherto accepted the general interpretation of Hegel advanced by his Dalhousie colleague and friend James Doull and by Oxford philosopher Michael Foster. However, Emil Fackenheim, a philosopher at the University of Toronto, had drawn his attention to the writings of Leo Strauss, and through Strauss, he encountered the great Hegelian interpretation of Alexandre Kojève, ${ }^{9}$ in whose writings he discovered an explanation of the expansionary politics of global imperialism. During the 1960s Grant began with increasing urgency to consider the impact of this development, the spread of modern technological civilization throughout the world, most especially as it had taken shape in North America. Lament for a Nation (1965) was in part an attempt to show how the disappearance of Canadian sovereignty was the result of the movement in history towards what Grant, following Kojève, called 'the universal and homogeneous state.' He not only warned his fellow citizens of the destruction of their country's independence, but also attacked the spread of American civilization around the globe, most particularly in his opposition to the increasing American involvement in Vietnam.

The Vietnam War, he was slowly coming to understand, took on its terrifying dimension because it arose out of a new 


\section{xii Editor's Introduction}

understanding of the nature of human existence. In Philosophy in the Mass Age Grant had come to see time as history as a direct development from the biblical account of time. He attributed his radical new insight in part to his friend the poet Dennis Lee, who, he wrote, 'understood that at the heart of our civilization lay an affirmation about "being" which was that civilization's necessity. The rampaging decadence of imperial war was not to be explained (within liberalism) as an aberration of our good system; it was not to be explained (within marxism) as something understood in terms of the dynamics of capitalism. In the very roots of Westem civilization lay a particular apprehension of "being." " ${ }^{10}$ Grant now knew that his task was to understand this particular vision of what it was to be human and how it had come to dominate in North America.

\section{Friedrich Nietzsche}

When the CBC invited Grant to deliver a series of radio lectures in 1969 (named the Massey lectures in honour of Grant's uncle, former Governor-General Vincent Massey), " he decided to focus on the thought of the nineteenth-century German philosopher Friedrich Nietzsche. He had come to the conclusion that Nietzsche's philosophic insights, more than any other thinker's, illuminated the background against which modem events, such as the Vietnam War and the growing Americanization of the Canadian economy, were moving. His task was to develop his insights in a form that would make them accessible to a large radio audience.

It was his son William, as he put it in the dedication to Time as History, who taught him to read Nietzsche. The dedication may have been meant more affectionately than literally. William, like so many young men and women in the sixties, was spiritually troubled by the world in which he lived. One of the thinkers he happened upon, in his last year of high school, was Nietzsche, and he was immediately and intensely excited by 


\section{Editor's Introduction xiii}

the ideas he found there. So that he could discuss his son's new enthusiasm, Grant began to reread Nietzsche. To his surprise he discovered a thinker who threw a brilliant light on the character of the very technological modemity he himself had been trying to understand for the past two decades.

In a sense Nietzsche was an intellectual acquaintance of long standing. Shortly after Grant's twenty-first birthday, while he was still a student at Balliol College, Oxford, he read Thus Spoke Zarathustra and wrote to his mother that Nietzsche had been completely misunderstood by most people: 'To say that he was the forerunner to such bestiality \& cruelty as the Nazis is absurd. "I love him whose soul is deep even for wounding \& whom a slight matter may destroy." "Pity is the cross upon which he is nailed who loveth mankind." That kind of thing is not like what he is supposed to be. He uses the theory of the "blond animal" in utter derision; yet people say that that is the basis of Nazidom.' 12

It was a decade before Grant referred to Nietzsche again, and only in passing in his doctoral thesis on the thought of the Scottish Presbyterian theologian John Oman. Although he described Nietzsche as an instance of 'pagan irrationalism,' he compared his thought favourably with 'the post-war daemonisms' of Céline or D.H. Lawrence. ${ }^{13}$ However, he curtly dismissed Nietzsche's attack on Christian morality in the following words. 'It also hardly seems worth noting in 1950 that Oman in dealing with Jesus as our ethical Lord makes short shrift of ideas such as Lawrence's and Nietzsche's that poverty of spirit means the morality of the slave. Presumably such ideas were more current among European intellectuals in his day than this. ${ }^{~} 14$

Nietzsche, Grant slowly came to understand throughout the 1950s, was not revered by North American thinkers, but those he had influenced were. Grant had turned his attention in the mid-1950s to the French writer and thinker Jean-Paul Sartre, ${ }^{15}$ who had been influenced by Nietzsche's greatest twentieth- 
century student, the German philosopher Martin Heidegger. He had also begun to wrestle with the impact of Freud on modem psychology ${ }^{16}$ and that of Max Weber on modern sociology and the practice of social work. ${ }^{17}$ By 1962 , when he delivered a $\mathrm{CBC}$ radio lecture on the psychoanalyst C.G. Jung, he had begun to consider Nietzsche's influence more explicitly. 'It is surely no accident that Jung grew up in that Germanic generation which was so deeply shaped by Nietzsche. For Nietzsche's attack on Semitic religion went more to the heart than any other of the many attacks which have characterized the last centuries; and it was made exactly at this point - man should pass beyond good and evil. ${ }^{18}$ Thus when Grant's friend James Doull wrote to him in 1968 about 'Heidegger and Nietzsche, who have drawn your attention anew' as authors who need 'far better interpretation than they have had,' ${ }^{19}$ even he did not know that Nietzsche's thought had been percolating in Grant's brain for almost thirty years. ${ }^{20}$

Grant's key insight between the time he wrote Philosophy in the Mass Age and Time as History was that our conception of history had decisively changed over the past hundred years. The Platonic idea of time as the moving image of eternity had been replaced, as he had argued in the earlier radio lectures, by the idea of history as a process within which events took place. Moreover, for the earlier historicists, such as Marx and Hegel, the process as a whole took its meaning from the end towards which it aimed, and thus gave individual events their meaning in terms of that end. However, Nietzsche was more radical; for him, events were merely episodic moments of pure becoming, and all meaning was subjective. As Grant explained in Time as History: 'History (call it, if you will, "process") is that to which all is subject, including our knowing, including God, if we still find reasons for using that word' (p 11).

George Grant was never a Nietzschean, although his praise for Nietzsche's brilliant analysis of the nature of modemity 
was at times so fulsome that some readers have been mislead; this was easily done because he had such an exceptional ability to articulate positions other than his own with ease and lucidity. Grant considered that Nietzsche's central thought (which is so familiar to us that it 'does not seem very new today') explained better than anything Grant had previously read why modem men and women seem unwilling to accept the old moral restraints of natural law. As he put it in the broadcast version of the fifth lecture: 'Nietzsche thinks what it is to be a modem man more comprehensively, more deeply, than any other thinker, including Marx, including Freud, including the existentialists, including the positivists.' Nietzsche excelled all these others because, in recognizing and preaching the historical sense, he had declared that all frameworks, all perspectives, were human creations. He called these 'horizons,' and announced that all they had ever done in the past was to express 'the values that our tortured instincts will to create' ( $p 40$ ). The most important and enduring of all these horizons had been God, but Nietzsche had declared that the horizon known as God was dead to Westem human beings; that is, the morality, religion, and law that historically had given meaning to human life no longer did so. But Nietzsche was not a simple atheist of the Enlightenment who believed that once the infamous thing had been erased all would be well; he accepted that the death of God, although it made possible the complete liberation of human beings, also posed enormous danger to the civilization that had discovered it.

North America, Grant now came to understand, was a progressive civilization, 'a dynamic civilization and that dynamism has been related to the fact that our apprehension of temporality was concentrated on the future' (p 20). As the purpose of existence became more opaque, human beings increasingly sought to control their existence through a science that mastered and controlled nature: 'Their concentration on mastery eliminated from their minds any partaking in time other than 
as future' ( $p$ 20). In North America the Puritan emphasis on willing, which it took from the biblical tradition, "was experienced as a pure potentiality' ( $p$ 20). North America became the realm of resolute willing, a place where we were, above all, determined to impose our stamp on existence. 'The will to change the world was a will to change it through the expansion of knowledge' ( $\mathrm{p} 25$ ).

Those in power in North America, Grant generalized, did not believe that it was possible to discover transcendent truths about how human beings should live. In the absence of such knowledge, they adopted what they sincerely believed was the only option for humanity - a creative plan to master the planet. For these moderns, "changing the world becomes ever more an end in itself' ( $p$ 27). The person who had 'thought the conception of time as history more comprehensively than any other modern thinker before or since' ( $p$ 32) was Nietzsche. And he had also understood better than anyone else 'the profundity of the crisis that such a recognition must mean' ( $p$ 32).

Previous thinkers such as Hegel and Marx had celebrated history, while also preserving a concept of human nature. Nietzsche, in Grant's view, exploded the inadequacy of their attempt. Grant quoted Nietzsche's aphorism from Human, All Too Human: 'Lack of historical sense is the inherited defect of all philosophers' ( $p$ 36). Charles Darwin had taught that species of animals are in continual change: they come into being and pass away. Nietzsche took the radical step of extending the idea of constant change to human beings. As Grant explained: 'What is fundamental about all human behaviour (including our understanding of it - itself a behaviour) is its historicity.' There was, therefore, nothing stable or enduring either in nature or in us. 'It is the apprehension that in the shortest moment we are never the same, nor are we ever in the presence of the same. Put negatively, in the historical sense we admit the absence of any permanency in terms of which change can be measured or limited or defined' ( $p$ 37). 


\section{Editor's Introduction xvii}

In the fourth lecture of Time as History Grant turned to the works of Nietzsche's maturity - Thus Spoke Zarathustra, Beyond Good and Evil, and The Genealogy of Morals - to explore the implications of this discovery for North America, whose destiny it was, Grant continued to affirm, to experience modernity in its fullest development. The discovery that time was history and nothing more was a discovery of great danger because it completely hid the last residual traces of the old tradition. These had been found in modern movements of progress such as liberal democracy and social democracy, which were the secular inheritors of the belief that there was some fundamental way in which all human beings were equal. The Christian tradition had affirmed the equality of human beings, since each human being possessed a soul. The death of God makes the basis of equality problematic. Grant quotes the famous passage in Thus Spoke Zarathustra to make his point: "The masses blink and say: "We are all equal. - Man is but man, before God - we are all equal." Before God! But now this God has died' ( $p$ 43).

Marx and Hegel had put a 'net of inevitable success' under the actors in their historical drama. For them, although the process of bringing history to fulfilment might involve pain and sacrifice, the actions of human beings are guaranteed from the ultimate anguish' ( $p$ 48). However, if we are the creators of history, there is no inevitable outcome. The last men, as Nietzsche called the banal pleasure seekers, or the nihilists who prefer to will destruction rather than not willing at all, may be in charge of the earth 'for centuries and centuries' ( $p 48$ ).

It is our fate, then, to live in a civilization that conceives time as history. Yet this fate, Grant affirms, is not 'one in which I think life can be lived properly. It is not a conception we are fitted for' ( $p$ 58). Nietzsche thought that it was, if only we could leam to love our fate, to overcome revenge, and to make our willing take place out of a positive love of the earth. Grant finds Nietzsche's call to will out of love of the earth 
inadequate: 'I do not understand how anybody could love fate, unless within the details of our fates there could appear, however rarely, intimations that are illumined; intimations, that is, of perfection (call it if you will God) in which our desires for good find their rest and their fulfilment' ( $p$ 60).

In the phrase 'intimations of perfection,' Grant was alluding to St Anselm's celebrated ontological argument, ${ }^{21}$ the argument for the existence of perfection. Grant, in fact, accepted St Anselm's argument as the only valid proof of God's existence; and it was of central importance because it led to the conclusion "that human beings are not beyond good and evil and that the desire for good is a broken hope without perfection, because only the desire to become perfect does in fact make us less imperfect' ( $p$ 60). However, Grant also knew that his personal and philosophic beliefs were not widely shared by his contemporaries. Their belief that it was possible to live decent lives outside this knowledge meant, in Grant's words, that 'the present darkness is a real darkness' ( $p$ 68) because the 'enormous corpus of logistic and science of the last centuries' had separated us from 'those images of perfection that are given us in the Bible and in philosophy' (p 68).

Yet a sun hidden by the clouds is still in the sky. Although it is difficult to see it, we need some point, however obscured, by which to orient ourselves in the world because, as individuals, we are called upon to make moral choices, and those choices will be all the harder since we live in a world that has given itself to dynamic willing. For Grant the Vietnam War was both symbolic and symptomatic of the type of moral crisis to which we would increasingly find ourselves called upon to respond. 'This is the crucial question about citizenship in this era: What is it to be a citizen in this new society ruled by its technical apparatus?' 2 It was hard, he told the idealistic students at the 1965 teach-in at the University of Toronto, to fight such a vast, imperial power-structure. But it was as necessary as it was liable to fail. The following words were an 
injunction to guide each individual who lived in modem technological civilization: 'I am not advocating inaction or cynicism. Nothing I have said denies for one moment the nobility of protest. Nothing I have said denies that justice is good and that injustice is evil and that it is required of human beings to know the difference between the two. To live with courage in the world is always better than retreat or disillusion.' ${ }^{23}$

Grant's writings, Time as History among them, often strike readers as bleak and austere. In frustration, they attack Grant for offering no solution, no guide to action. Yet Grant constantly affirmed that he was not a pessimist, that no one who believed in God could possibly be a pessimist. In an aside in Time as History he noted that 'the absence of all nets is a truth that those of us who trust in God must affirm' ( $p$ 48). Even faced with the abyss, it was always open to each of us at every moment to think and love what is good. That possibility might not seem like much, but fortunately, it was enough. God was always there if we chose to turn to Him. 'It may be that at any time or place, human beings can be opened to the whole in their loving and thinking, even as its complete intelligibility eludes them' ( $p$ 68).

\section{New and Uncertain Thoughts:}

Grant's Later Nietzsche Seminars

Publication of Time as History was delayed until 1971 because Grant was seriously injured in an automobile accident while on vacation in Barbados in May 1970. As a consequence of his stay in hospital and his long convalescence at home, the text of the published lectures was substantially the same as the broadcast version. However, Grant was not yet content that he had come fully to terms with Nietzsche's enucleation of modemity.

Grant was very conscious that he taught in a religion rather than a philosophy department, but, as he understood it, that 


\section{xx Editor's Introduction}

position made it even more appropriate that he address Nietzsche's thought. For Grant, modemity, with its drive to dominate human and non-human nature, was the new religion of North America. The religion of progress, which originated as an outgrowth of secularized Christianity, was the unquestioned faith that bound most North Americans together. It was a new religion and it had definitively replaced Christianity as the dominant faith. ${ }^{24}$ It was therefore not just appropriate, but necessary, to explore the thought of Nietzsche who, although he too rejected the doctrine of progress in its Enlightenment form, had thought through the implications of the new faith most clearly.

Grant began his 1969-70 Nietzsche seminar by reading his Massey lectures and making a typewritten version available to his students. However, as always, he intended in his seminars to explore matters with which he had not dealt in his published work. As he explained to his students: 'Let me say in parenthesis that what I am certain about I generally write down and do not repeat in this class. I do not repeat them [sic] in class because I think it impertinent to you to repeat what you can read of mine in print if you so desire. Professors who go on repeating their books in a class are a bore; people who need that should just read the books. It is one's new and therefore uncertain thoughts one should give in class. ${ }^{25}$

The new theme Grant wanted to explore was Nietzsche's fundamental criticism of the "tradition of revelation (faith) and metaphysics (reason) in the West. ${ }^{26}$ Grant accepted the dominant Westem position that it was impossible to do theology without metaphysics. However, the meaning of one of the important terms in this equation had drastically changed: the modem understanding of reason, originating with Descartes and culminating in Nietzsche's 'supreme attack on theology' had overwhelmed the ancient understanding of reason, which had been brought to its highest and clearest point in Christianity, particularly by St Augustine. In contrast, the modem ac- 
count of reason 'tells us we must be atheists. '27 In Grant's view, most contemporary theologies, both Catholic and Protestant (including philosophers such as A.N. Whitehead) are necessarily incoherent "because they do not come to terms with what Nietzsche says.' $z z$

The classical account of reason, by itself, did not necessarily lead to theism: 'Obviously Aristotle was no theist. ${ }^{29}$ Reason had to be understood, Grant argued, in its Platonic version, and that was a long and difficult endeavour. It was equally a necessary one, especially for those in the English-speaking tradition, because the English-speaking peoples had evaded the question by falling back on their faith in liberalism, but that liberalism was now totally riddled with contradictions. ${ }^{30}$

The theoretical and practical inadequacy of modem liberalism was to take on increased urgency when his wife, Sheila, drew his attention to the landmark American Supreme Court decision delivered by Mr Justice Blackmun in Roe v. Wade (1973). Sheila Grant had been active in the right-to-life movement, and her concern about the implications of the American decision brought Grant into the controversy. He addressed the question directly in the Wood Lectures entitled 'English-Speaking Justice,' delivered at Mount Allison University in Sackville, New Brunswick, early in $1974 .{ }^{31}$ That legal judgment, with its denial of rights to foetuses, was for him a symbol of the theoretical and practical confusion into which the Englishspeaking world had fallen as a consequence of its acceptance of the modem doctrine of rationality. ${ }^{32}$

When he addressed the problem of Nietzsche again in his 1974-5 graduate seminar, therefore, the matter was, for him, an increasingly urgent one, and he gave the course jointly with the department of political science, as he explained, because 'it seems to me unwise to divorce the question of what constitutes the good political order and what it is proper for human beings to reverence. ${ }^{33}$ Human beings, as beings open to the whole, unavoidably needed to face the question of what con- 


\section{xxii Editor's Introduction}

stitutes the good life, and this question faced modem men and women as beings who inhabited a 'world-wide society based on the pursuit of the conquest of human and non-human nature. ${ }^{34}$ The possibility of such a society was known to the ancients, particularly Plato, but he "turned away from such a society as not conducive to human good.' The novelty lay not in the potentiality of such a society, but in its actuality. It was Nietzsche, Grant declared, even more than his great predecessors Kant and Hegel, or his only great epigone, Heidegger, who had 'thought what is being thought in that modernity more comprehensively and completely than any other thinker. ${ }^{35}$

In the older tradition, a 'truth' was an affirmation about existence. In the modern tradition, truth was a value and value was something created by human beings. But human beings need horizons in order to live, and the truth taught by modern science was that there were no horizons, that there was no stable existence, no being - only becoming. Truth, thus conceived, was a devastating discovery for human beings; this kind of truth killed life, since in the flux of existence, there was no moral point by which human beings could orient themselves.

In Nietzsche's philosophy, Grant argued, the highest life was the life of freedom, but freedom requires that becoming somehow be stabilized. Such stability could be attained only by the imposition of will on nature. The positive consequence of this stabilizing of becoming was that it allowed human beings to establish the conditions that permitted human life. There was, however, a negative side. The exaltation of the value of truth in the Western tradition closed down the highest vision, the Dionysian vision, that is, life as tragedy. Unless truth as it was understood by modern science were overcome, the highest type of human being, the Übermensch (overman or superman) could not come to exist. Plato had taught that the height for human beings was philosophy; Nietzsche attacked philosophy in the name of tragedy and the possibility of the higher human being. To face the abyss of existence as tragedy 


\section{Editor's Introduction xxiii}

is a tremendous and dangerous task 'because it might drive us mad - like it drove [Nietzsche] mad. ${ }^{36}$

Although Grant had hitherto celebrated Nietzsche as the thinker who had most comprehensively thought about modem western civilization, he now no longer saw Nietzsche as the culmination of the Enlightenment. Nietzsche was not, in Grant's eyes, simply 'the thinker who catches the very swell of the ocean of modernity.' He was far more radical than that; he was someone who 'is not content to swim with that current - but [who wants to] find other currents than that. ${ }^{37}$ This rejection of progress put Nietzsche at odds with the great political movements of the nineteenth century, liberalism and marxism. Both these ideologies contributed to the popular atheism of the West in the name of liberating human beings from the dead hand of religious institutions; but Nietzsche saw that popular atheism was leading to the creation of a 'much lower type of man than was produced by the theism of the past. The death of God, according to Nietzsche, is opening up this great degradation of man - the last men who are lower than past men who lived under theism. ${ }^{36}$ Nietzsche's atheism, by pointing to the higher man, was thus fundamentally different from the atheisms that preceded it. His was a new, rightwing, atheism. Intellectually, it was more honest than the leftwing atheism it attacked; but left-wing atheism was 'morally preferable to the right-wing atheism, just because it is secularized Christianity and Judaism. ${ }^{39}$

For Grant, following Leo Strauss's argument in his essay 'The Three Waves of Modernity,' ${ }^{40}$ the critical development was the abandonment of the standard of nature as a transcendent source of the good for human beings. The first of Strauss's waves involved 'the rejection of the ancient account of nature conceived teleologically. ${ }^{41}$ Hobbes and Locke were the great thinkers in this development. For them, although they saw no ends or purposes given in nature, they still took nature as the standard from which we divine, albeit negatively, our knowl- 


\section{xxiv Editor's Introduction}

edge of the just regime. ${ }^{32}$ The second wave of thinkers - Rousseau, and most of all, Kant, Hegel, and Marx - rejected nature as the standard 'in the name of the discovery of history as the standard. ${ }^{43}$ This development implied the understanding of human beings pre-eminently as 'free animals." ${ }^{44}$

The third wave of modemity, which dominates contemporary thinking, rested on the assertion that "history is not rational and cannot provide us with the standards from which we come to have knowledge of the just regime' ${ }^{45}$ This last wave was inaugurated by Nietzsche, and led to the prevalence of a life-denying historicism in both scholarship and practical life. Hegel's thought (as well as Marx's and Mill's), whatever its high ideals, reinforced a dangerous momentum towards nihilism.

Nietzsche accepted the position that the truth about the highest matters is radically historical, and that there is therefore no truth that man can ever possess which will not prove to be in need of radical revision. However, in 'The Advantages and Disadvantages of History for Life,' he moved decisively beyond the Hegelian position when he recognized that the truth of historicism is deadly for human beings; in Grant's words, 'We cannot live on the basis of the purely personal and relative character of our principles. ${ }^{\text {}} 46$

The twentieth-century existentialists interpreted this aspect of Nietzsche's teaching in terms of the free project, of free creation. In this, Grant thought, they misunderstood Nietzsche who, in his 'great admiration for the Greeks' conceived of culture as idealized nature. The word 'nature' is, of course, notoriously ambiguous, and this ambiguity is also present in Nietzsche who uses the word in both its popular sense and also in a way uniquely his own. In his early work, Grant argued, Nietzsche accepted technology - the conquest of nature - and therefore espoused the modem position in his acceptance of the view that it was not possible to talk of the nature of human beings because human nature itself had been conquered. In 


\section{Editor's Introduction $\mathbf{x x v}$}

siding with the moderns in accepting that nature could not impose limits on human action, Nietzsche decisively rejected a view that lay at the core of ancient thought. In contrast with modem egalitarianism, Plato and Aristotle saw the non-egalitarian society as natural, and in his later writings Nietzsche sought to retain both views: he still wanted the modem conception of nature, but he wanted 'it in a way that will include the order of rank against egalitarianism.' This insistence on order of rank created a central political difference between Nietzsche and the exponents of both marxism and American liberalism. But they all agreed on one important matter, namely that the rule of human beings should replace the rule of chance. The overcoming of chance in turn meant the technologized society, 'the society dedicated to the conquest of human and non-human nature.'

However important these political questions were, they paled into insignificance compared to Nietzsche's great attack on the division between thought and the saints, or 'if you prefer, between thought and charity.' Grant rejected the position advanced by thinkers as diverse as Tertullian and Leo Strauss that there was a great division between Athens (philosophy, rationality) and Jerusalem (revealed religion, faith): 'I just deny that division. ${ }^{\prime 8}$ Reason could always understand what charity commanded. It was clear that Nietzsche rejected revelation, but how did he stand with regard to metaphysics? He attacked 'what has been called in the tradition metaphysics,' but his doctrine of the will to power seemed, and was so interpreted by Heidegger, as a metaphysical doctrine in its own right.49

To understand Nietzsche's doctrine of the will to power, it was necessary to resolve the question, Who is it that wills? This brought Grant to consider the question of the self in Nietzsche's thought, a topic 'deeper' than he normally raised in class. ${ }^{30}$

Nietzsche attacked not only the ancient, Platonic-Aristotelian, doctrine of the soul, he also rejected the teaching of modern 
philosophy from Descartes to Hegel, which spoke in terms of ego and subject. The oldest tradition, which understood soul as spiritual substance, stood in the way of modem science's conquest of human and non-human nature, because its vision entailed the unchangeability of this substance. Modem science emerged when the soul was divided into two phenomena: (a) the consciousness or ego, and (b) the body as matter or nature. Animals were subject purely to mechanical processes. 'In the case of some beings, perhaps only man, these mechanical processes are accompanied by consciousness. ${ }^{\text {'s }}$ Nietzsche repudiated this post-Cartesian view in a way that put him closer, in some respects, to Plato than to Descartes or Kant. He did so in the name of the subconscious, an aspect of human beings that "can never be made conscious. ${ }^{\text {'2 }}$

It was Sigmund Freud who popularized the concept of the subconscious, but Freud's view departed from Nietzsche's. Freud never said unequivocally that the subconscious could never be made fully conscious. To the extent that Freud saw psychoanalysis as a science, the movement of the subconscious to consciousness was a process that, in principle, was capable of infinite progress. Nietzsche's self was creative; indeed, it usurped the role of the creator God. It was at heart something mysterious: 'The self is the abyss of freedom in the soul.' By the Übermensch or superman, Nietzsche meant nothing less than 'the mysterious self which has taken the place of the mysterious God.'s3

As bodies, human beings are driven by their passions. This was the teaching of a series of philosophers, of whom Grant singled out Hobbes, Spinoza, Hume, and Montesquieu. The key statement was Hume's affirmation that reason was, and could only be, the slave of the passions, and by this he meant that reason was a kind of calculation.

For Plato the conflict between the passions concerned a contrariety towards the same object of desire, at its highest the desire for the whole. The idea of the whole was accessible to 


\section{Editor's Introduction xxvii}

human beings, and the question facing us when we experienced contrariety of desires was, Which desire was rational? Happiness (in Greek, eudaemonia) was the soul at unity with itself "because it partakes in that which is the source of all unity - the i $\delta \varepsilon \alpha \tau \sigma o v \dot{\alpha} \gamma \alpha \theta$ ov [the idea of the good].' Virtue was the state in which the passions find their proper and just order of 'subordination and superordination within the soul as a unity.'

In the seventeenth and eighteenth centuries, modern philosophers rejected this concept of virtue in favour of the view that virtue was itself a passion, albeit a good passion. Thus altruism or compassion had to fight the bad passion of selfishness. Their conclusion was that history had shown that reason (understood in the Platonic way) in the hands of the philosophic few was simply not a secure and effective means to control the passions of the unphilosophic many. The triumph of virtue would occur only when human beings understood that virtue, too, was a passion. This led to the recommendation that the good passions must be emancipated so that they might prevail against the bad passions. For example, Hobbes argued that it was necessary to liberate the fear of violent death, because it was only on that basis that it was possible to build a fairly rational society. The good passions give reason the strength to triumph in society.

Nietzsche carried this argument further in a way that put him simultaneously closer to, and farther away from, Plato than his immediate predecessors. He was nearer to the extent that he thought that virtue, as sublimated passion, was the highest passion; it was something sublime. However, he was farther away from Plato because he thought that the virtues were something different in each human being. To Nietzsche their similarity was merely one of names and they had nothing to do with reason.

Both Nietzsche and his modern predecessors agreed that, to liberate the beneficial and virtuous passions, it was necessary 
to break with the very idea of tradition, a word Grant often used to mean religion ('tradition [call it if you will religion]').s5 Nietzsche not only started from the modem attack on religion, he understood the core of modernity better than its originators and, most important, he passed beyond them when he advanced his celebrated doctrine of the eternal recurrence of the identical.

The doctrine of eternal recurrence of the identical was Nietzsche's response to the modern attempt to overcome chance. As Grant had argued in Philosophy in the Mass Age, the redemption of the past, the overcoming of its suffering and follies, had, for Marx, depended on the fact that history was moving to a future in which exploitation and oppression would finally and forever be overcome. For Nieizsche, Marx's answer would not have sufficed, because it was still dependent on the spirit of revenge, revenge against the past. The will, however, is impotent against the past, because it cannot change it. 'The past is the very character of time itself - to pass away. ${ }^{36}$ What can the will do in order to counteract its defeat by time?

Now Nietzsche saw that the past fragmentedness of human beings could be overcome, not by the conquest of fragmentedness and chance but by redeeming them. This 'redemption consists in the willing of fragmentedness - the affirmation of chance.'st All previous thought, be it Plato's or be it Marx's, sought revenge on time. Plato, Nietzsche charged, had conjectured the etemal precisely in order to get his revenge on time. Platonism and Christianity had degraded nature by positing the supernatural out of a spirit of revenge against time. Even marxism and liberalism were tainted by revenge in all its corrosiveness; as 'progressive' theories, they looked to future progress to redeem the suffering and injustice of the past. Nietzsche soared above both marxism and liberalism because he was also 'aware that nothing that is not eternal can satisfy a thinking man.'s8 
To sum up. The superman becomes possible through deliverance from the spirit of revenge, from every [need] for the eternal which is beyond the perishable. The flux is willed. Time and the pasts are willed, and that means to will the return of the past. Willing the eternal return is the peak of the will. Through liberation from the spirit of revenge the will becomes properly willed because it has freed itself from that which frustrates the will.

Now this does not mean that Nietzsche ceases to be a modern in that he abandons the will to the future. He wills the future while willing the past - in one and the same act. But he passes beyond the great progressives such as Marx because the willing the past means the return of the past. We will the future and the past - but that is only possible if time is a circle, a recurrence of the past. ${ }^{59}$

Human beings have always resented the past conceived as eternal becoming because such a concept entails their eventual annihilation in death. Socrates had taught that philosophy was the practice of dying. In Grant's words, 'philosophy is meditation upon the fact of our finitude - upon death. ${ }^{60}$ The Christian tradition intensified this concern because at the centre of Christianity was a death. ${ }^{61}$ Spinoza, however, announced that philosophy should not be a meditation on death, but upon life, and in this he was followed by the great progressive thinkers such as Marx.

Nietzsche's doctrine of the eternal recurrence of the identical was his meditation on death, and it is precisely because he brought 'meditation on death' back into philosophy that he passed beyond modem thought. Surprisingly, Grant declared that his sympathy lay somewhere between Nietzsche's teaching and the traditional understanding of the uniqueness of Christ's crucifixion, which had been brought into Western Christianity by St Augustine and spread throughout the world by Calvinist Protestantism. He did not believe that the cruci- 


\section{$\mathrm{xxx}$ Editor's Introduction}

fixion was a limited historical event; other revelations and redemptions might be granted. For example, in India, Christ's name might be Krishna (or as Simone Weil says, 'Wherever there is affliction, there is the Cross') ${ }^{62}$ Grant claimed that he always reminded himself of his disagreement with the doctrine of the sacrifice, once offered, ${ }^{63}$ when his Anglican vicar was reciting the prayer of consecration. 'Is Christianity fundamentally committed to the unicity of the historical process? If so, one has to give up Platonism. I hope not, but I am not sure. ${ }^{64}$

Grant found the doctrine of etemal recurrence of the identical an attractive correction to the view of time as history: 'It is ... a doctrine of the trans-historical whole of nature.' However, it was not a fully satisfactory solution to the modern conception of time because 'it is not in itself, nor is meant to be, a rational doctrine.' It is a strange mixture of the two - an enigmatic, that is allusive, vision. Above all, it is a teaching that concerns the universal, and it is precisely the lack of a vision of the eternal (Leo Strauss's oblivion of eternity) that stands at the centre of modernity. In the tradition, that is religiously, universality cannot be avoided because human beings are rational beings, 'and universality is the expression of our rationality.' ${ }^{65}$ Nietzsche's doctrine of the eternal recurrence of the identical brought back a teaching concerning the trans-historical whole of nature. But it did so at the level of nature, not at the level of reason.

At the level of reason, Nietzsche's perspectivism prevented an affirmation of transcendence. All knowledge serves historically specific life and is, therefore, interpretation. Fundamentally, this teaching absolutely affirms the doctrine that all knowledge is creation. Modern social science, especially that deriving from Max Weber, has accepted this side of Nietzsche's teaching, but in Grant's view, it has done so only partially. Nietzsche realized that it was impossible to claim historical relativism as an absolute truth. He also understood that 


\section{Editor's Introduction $\quad x x x i$}

historical relativism is a deadly truth. Most important, though, the objective truth of historicism 'call it if you will God is dead $^{166}$ must itself be interpreted, and that interpretation can be either noble or base. The base interpretation is ordinary relativism; the noble one is creativity. Most social scientists think that the relativist interpretation is more scientific, but Nietzsche affirms that both the base and the noble interpretation are 'quite outside science.' ${ }^{\prime}$ The noble interpretation of historicism is human creativity understood as the will to power, or one's own self-awareness of one's own creativity.

The heart of the noble teaching accepts that there is nothing eternal except individuals in their individuality, but it allows an infinite affirmation of life with all its sufferings and defects in a way that is not possible in the base interpretation. The superman makes the retum to nature possible because he shares with the beasts something that distinguishes both from historical man - harmony and unity within the cycle of nature.

Nietzsche's thought is worthy of study because of the clarity with which he enucleated modernity. Yet Grant declared that he reacted to Nietzsche's philosophy with a 'limitless repugnance,' which he had never felt so strongly as during that year's course. 'Nothing could be more repugnant than the doctrine of human beings as creative - indeed of philosophy itself as creative ${ }^{\prime 68}$ Creativity, for Grant, always remained the unique prerogative of the Creator God.

\section{The limitless repugnance}

Nietzsche continued to occupy Grant's thoughts until his death in 1988, although he increasingly found Jean-Jacques Rousseau's writings, especially his Discourse on the Origin of Inequality among Men, more illuminating than Nietzsche as a source of the modem understanding of human beings as historical creatures. In 1981, he wrote to a friend: 'I am going to write a piece - a long one - called "History and Justice," which 
is to go into a book called "Technology and Justice," which I hope to publish next year. The piece on "history" will be about Rousseau who I now see as as great a founder of modemity as Nietzsche. I think I have at last seen with some clarity something I have never seen before as to what modem people mean by "history." 69

However, he retumed to Nietzsche when he began to study Heidegger's four volumes of engaged commentary on Nietzsche's thought in an English translation. ${ }^{70}$ As we have seen, Grant kept his more uncertain thoughts to the privacy of his classroom, only setting his ideas down for publication when he was confident that he had thought through the matter with sufficient clarity.

This was never a precipitous process and it took him almost a decade to bring his thought about Nietzsche into its final form in Technology and Justice (1986). ${ }^{71}$ It had not even been until 1979, four years after his Nietzsche seminar at McMaster that he had brought himself to explain in public some of the grounds for his repugnance for Nietzsche's doctrines in 'Nietzsche and the Ancients: Philosophy and Scholarship. ${ }^{172}$ The first part of this article raised the question of historicism in the context of Nietzsche's critique of Greek, especially Socratic, rationalism. In the second part he explained why he found Nietzsche's writing unsatisfactory. Nietzsche, above all, provided the 'root and branch' critique of the Platonic tradition. Grant, in effect, proposed to retum the favour. 'If I were not afraid of being taken as an innocent dogmatist, I would have written that one should teach Nietzsche within the understanding that he is a teacher of evil. ${ }^{73}$

Unlike those who reject Nietzsche because they find no explicit teaching about justice in his writings, Grant affirmed that such a teaching is "at the very core of what he is saying. ${ }^{174}$ And Grant found that teaching frightening. He quoted a fragment from The Will to Power (1884) in which Nietzsche wrote: 'Justice as function of a power with all encircling vision, which 


\section{Editor's Introduction xxxiii}

sees beyond the little perspectives of good and evil, and so has a wider advantage, having the aim of maintaining something which is more than this or that person.'

What frightened Grant about this formulation was that it seemed to give an account of justice 'as the human creating of quality of life. ${ }^{\prime \prime}$ However, such creativity amounts to abandoning the truth of the Platonic conception of justice as giving to others their due. It does so by suggesting that there are some human beings to whom nothing is due, other than perhaps extermination. More specifically, it affirms that there is nothing extrinsic that limits human creative potential, that puts any limit on what we may do in the pursuit of the great enterprise of creating a quality of life beyond the little perspectives of good and evil. 'Human beings are so unequal in quality that to some of them no due is owed. ${ }^{76}$ In the idea of the technological world, which is almost now fully incarnated, this stance is the full consequence of the oblivion of etemity which has taken hold of Western thought.

It was not until 1986 that Grant finally believed he had come to terms with Nietzsche's thought in such a fundamental way that he could reject its most fundamental conclusion: that the discoveries of modem science showed that God was dead, and that Christianity had produced its own gravediggers. This rejection took the form of 'Faith and the Multiversity," Grant's most profound critique of the modem project. Thinking the thought contained in Simone Weil's aphorism 'Faith is the experience that the intelligence is enlightened by love, ${ }^{, 78}$ Grant showed persuasively that the whole of modem science and the ethical relativism that gave it such power was fundamentally flawed by its failure to account for our undoubted experience that love exists in the world and that it enlightens us. 'Modern scientists, by placing before us their seamless web of necessity and chance, which excludes the lovable, may help to reteach us the truth about the distance which separates the orders of good and necessity. ${ }^{79}$ 
Nietzsche had argued that the Christian doctrine of the importance of truth had created modern rationalism, and modern rationalism had made Christianity a doctrine that could no longer be true for modem human beings. Although Grant, as we have seen, accepted this account of modem philosophy and its impact on subsequent Western thought, he now concluded that Nietzsche was right only as an historian, not as a philosopher.

Historically 'westem Christianity simplified the divine love by identifying it too closely with immanent power in the world. ${ }^{80}$ Both the Protestant and Catholic streams of Christianity were now paying the price for that failure and, to that extent, Nietzsche was right. This was a conclusion to which Grant had come as early as 1969 , when he told his class: 'It appears to me that it is just western Christianity, with its account of individuality, freedom and will, which leads straight to Nietzsche's formulation of the question ... Nietzsche does not seem to me anti-Christian, but his formulations seem to me to come out of western Christianity. ${ }^{\text {'81 }}$

Nietzsche sought to redeem humanity by placing what, in the tradition, were called moral judgments beyond good and evil. Grant considered this an 'atrocious price' to pay. Fully aware of the implications of what he was doing, Nietzsche took the "prodigious and, to some, unconscionable step of questioning western Christianity.' ${ }^{\prime 2}$ However, for Grant it was only western Christianity, a particular, although dominant, version of the Christian faith that had been undermined. Ironically, Nietzsche had helped to make clear 'what western Christianity seemed to forget in its moment of pride: how powerful is the necessity which love must cross. Christianity did not produce its own gravediggers, but the means to its own purification. ${ }^{83}$

Grant knew well from his own life how difficult it was to shake off the modern vision and to undertake the task of purification. He called the following statement, addressed to a class in 1969, 'the most intimate thing I have ever said in a 
class-room.' It was less a confession of failure than a statement, in response to Nietzsche, that he placed the life of charity, the life fully lived by a saint, above the life of reason or philosophy, his own life. Simone Weil, was in his view, a modern saint who had understood Christianity purely and had both expressed that understanding clearly in her philosophical writings and lived the life of renunciation to which her understanding of Christianity pointed. As Grant said then:

What is said in [Simone Weil's writings] seems to me the truth. That is, when the chips are down, this is what I think about what is, and no criticism of it has ever convinced me. Yet at the same time it is not something I am able to live by. That is, I obviously do not think it is true in the sense of truth in Plato, in which desire and reason must be one. That is, for ten years, I have been in the very horrible position of thinking this position to be true and yet turning away from it.

Why do I make this rather egocentric remark? Because the following is true: 'Human nature is so constituted that any desire of the soul in so far as it has not passed through the flesh by means of actions and attitudes which correspond to it, has no reality in the soul. It is only there as a phantom' [Simone Weil]. That is the supreme truth of Christianity - the Incarnation - everything divine has to come to us by passing though our flesh.

I think this doctrine to be true. I do not consent to it, because I do not consent to its passing through my flesh. Therefore, there is something very strange in my passing this doctrine on to you as true, when I do not consent to it in desire. Indeed, there is one saying in the Bible that is indubitable. 'It is a fearful thing to fall into the hands of the living God. ${ }^{\text {s4 }}$

Nietzsche's writings, then, by no means fully represent a final truth. To understand what Grant thought to be the truth about the highest matters, one must tum to 'Faith and the Multiversity,' 


\section{xxxvi Editor's Introduction}

in Technology and Justice (1986), his attempt to show how he participated 'intellectually in the mystery of Christianity. ${ }^{85}$ Without an understanding of the role of Christianity in Grant's thought, all discussions of Nietzsche are not only partial but misleading.

William Christian

Guelph, Ontario

August 1994

\section{NOTES}

1 George Grant, interview with David Cayley, 1985

2 George Grant to Mother, 8 November [1937]

3 George Grant to Gerald Graham, 30 November [1939]

4 George Grant to Dear Mum [early 1940]

5 George Grant, 'Address to History Society, University of Toronto,' probably 1970

6 George Grant, 'Charles Cochrane,' Anthology. CBL, 26 October 1954

7 George Grant, Philosophy in the Mass Age (Toronto: Copp Clark 1959; rpt., with an introduction by William Christian, Toronto: University of Toronto Press 1995), ch 4

8 For a discussion of Grant's indebtedness to Hegel's thought and the importance of Grant's friend James Doull, see Christian, Introduction to Philosophy in the Mass Age (1995)

9 Alexandre Kojève, Introduction à la lecture de Hegel (Paris: Gallimard 1947)

10 George Grant, 'Dennis Lee - Poetry and Philosophy,' in Karen Mulhallen et al., eds., Tasks of Passion: Dennis Lee at Mid-Career (Toronto: Descant 1982), 230-1

11 His predecessors were all equally distinguished: Northrop Frye, Frank Underhill, C.B. Macpherson, John Kenneth Galbraith, Paul Goodman, Martin Luther King, Jr, and Dr Ronald Laing

12 George Grant to Maude Grant, 22 November 1939

13 George Grant, 'The Concept of Nature and Supernature in the Theology of John Oman,' (DPhil thesis, Oxford 1950), 26 


\section{Editor's Introduction $\quad$ xxxvii}

14 Ibid., 170-1

15 George Grant, 'Jean-Paul Sartre,' Archilects of Modern Thought (Toronto: Canadian Broadcasting Corporation, 1955), 65-74

16 George Grant, Conceptions of Health, in Helmut Schoek and James W. Wiggins, eds., Psychiatry and Responsibility (Princeton: D. Van Nostrand 1962), 117-34

17 George Grant, Value and Technology, Conference Proceedings: 'Welfare Services in a Changing Technology' (Ottawa: Canadian Conference on Social Welfare 1964), 21-9

18 George Grant 'Carl Gustav Jung,' in Architects of Modern Thought, nos. 5 \& 6 (Toronto: Canadian Broadcasting Corporation 1962), 73-4

19 James Doull to George Grant, 11 October 1968

20 For Grant, such a period of contemplation was not unusual. He often thought about a writer for a decade or more before he was prepared to write down his thoughts on paper.

21 I think Grant would have been in substantial agreement with Iris Murdoch's argument in Metaphysics as a Guide to Morals (London: Allen Lane 1992), ch. 13, 'The Ontological Proof.'

22 George Grant, 'A Critique of the New Left,' in Dimitrios I. Roussopoulos, ed, Canada and Radical Social Change (Montreal: Black Rose Books 1973), 58

23 Ibid., 59

24 See 'Introduction' to 'Religion and the State,' in George Grant, Technology and Empire: Perspectives on North America (Toronto: House of Anansi 1969), 43-5. For Grant's account of how this new faith came to dominate in North America, see George Grant, English-Speaking Justice (Toronto: House of Anansi 1985), Part III.

25 George Grant, 'Notebook: Nietzsche starting with B[eyond] G[ood] and E[vil] Part 6.' The material in this notebook is fragmentary; that for 1974-5 is extensive. Grant's notebooks, which are written in McMaster University spiral-bound notepads, of the sort students use for taking lecture notes, contain both jottings and fully written-out lectures, which Grant would normally read at the beginning of a class. Because they are unpaginated and unpublished, I refer only to the notebook as the source. Peter Emberley and Arthur Davis plan to publish extensive selections from these notebooks in their edition of Grant's collected works.

26 Ibid.

27 Ibid. 


\section{xxxviii Editor's Introduction}

28 Ibid.

29 Ibid.

30 Ibid.

31 Grant revised these lectures very thoroughly, and they were not published until January 1978, although they bear a 1974 publication date.

32 'The natural rights tradition derives from the natural law tradition, specifically the idea that humans receive or consent to order. Dynamic willing refuses such receptivity and thus the "rights" posited by the will can, at best, be only conditional fictions.' I owe this formulation to an anonymous University of Toronto Press reader, to whom I am grateful for the important clarification.

33 George Grant, 'Notebook: Nietzsche Class 1974-5, Book I,' which actually fills two spiral-ring binders. Peter Emberley kindly provided me with a typescript of this notebook.

34 Ibid.

35 Ibid. For texts, Grant chose the works of what he called Nietzsche's third period, 'incomparably the highest, where he looks at the truth and deadliness of science and makes his great affirmations: Thus Spoke Zarathustra, his greatest work; Beyond Good and Evil, 'which is a commentary on Zarathustra'; and The Genealogy of Morals, in which he descended into the popular arena where he must write very directly and exoterically, 'a simpler, more popular, incomparably less ironic [work] than Beyond Good and Evil.'

36 Ibid.

37 Ibid.

38 Ibid.

39 Ibid.

40 See An Introduction to Political Philosophy: Ten Essays by Leo Strauss, ed. Hilail Gildin (Detroit: Wayne State University Press 1989), 81-98

41 George Grant, 'Notebook: Strauss on Historicism,' [early 1970s?]. However the notebook also contains material on Heidegger's view of Nietzsche, which almost certainly dates from the 1980 s.

42 Ibid.

43 Ibid.

44 Ibid.

45 Ibid.

46 George Grant, 'Notebook: Nietzsche Class 1974-5'

47 Ibid. 


\section{Editor's Introduction $\quad \mathbf{x x x i x}$}

48 Ibid.

49 George Grant, Notebook: 'Nietzsche Course, Part II, Zarathustra.' Grant offered four alternative explanations of its possible meaning:

1 Although Nietzsche tried to overcome metaphysical dogmatism, he unwittingly relapsed into it; or,

2 Nietzsche proposed the doctrine of the will to power merely as an hypothesis, but one that would become true to the extent that it is believed and acted upon by human beings; or,

3 The doctrine of the will to power is superior to all earlier metaphysical assertions and is the best possible doctrine for modern human beings. However, it is not simply true, because it belongs to a certain historical perspective, namely Nietzsche's. Subsequent ages will need their own life-affirming perspective; or,

4 Although the will to power belongs to a specific perspective, this perspective, analogous to Hegel's view of his own philosophy, is the absolute perspective.

50 Ibid.

51 Ibid.

52 Ibid.

53 Ibid.

54 Ibid.

55 Ibid.

56 Ibid.

57 Ibid.

58 Ibid.

59 Ibid.

60 Ibid.

61 Ibid.

62 Sheila Grant to William Christian, private communication, 2 June 1994

63 These are the words used by the Anglican Book of Common Prayer to refer to the crucifixion.

64 George Grant to Joan O'Donovan, [1982]

65 George Grant, 'Notebook: Nietzsche Course, Part II, Zarathustra'

66 Ibid.

67 Ibid.

68 Ibid.

69 George Grant to Joan O'Donovan, 25 January 1981. Grant did write a paper, 'Why Read Rousseau?' but it was never published. 


\section{xl Editor's Introduction}

70 Grant always considered Heidegger's work so profound and difficult that, although he mentioned it often in connection with Nietzsche, it was only at the time of his death that he was prepared to put his thoughts down on paper. This essay, 'Confronting Heidegger's Nietzsche,' exists only in fragmentary form, brilliantly edited and partially completed by his widow, Sheila Grant. There is no place, even in this lengthy introduction, to begin even a superficial analysis of Grant's thoughts on Heidegger-Nietzsche, and I happily leave the task to others much more qualified than I to undertake it.

71 As he explained to his friend and editor, Dennis Lee: 'I was writing a book called "Technology and Justice." English-speaking Justice was to be one part; the Nietzsche thing you mention was the national socialist part and I was working on the marxist part, when I came upon Rousseau (who I now take to be the founder of the Darwin-Nietzsche part). It was a great discovery because I realised he was a greater intellectual founder of modernity than anybody else and it stopped me trying to get down his greatness and his terrible results. So I have put aside "Technology and Justice" till I have written the Céline, largely because I was sick of negativity and criticism and was so enraptured by Céline.' George Grant to Dennis Lee, November 1983

72 George Grant, 'Nietzsche and the Ancients: Philosophy and Scholarship,' Dionysius 3 (December 1979): 5-16; rpt. in Technology and Justice (Toronto: House of Anansi 1986), 79-95

73 Ibid., 91

74 Ibid., 92

75 Ibid., 93.

76 Ibid., 94-5

77 George Grant, 'Faith and the Multiversity,' in Grant, Technology and Justice, 35-77. I am particularly concerned here with the discussion that Grant labels 'Appendix.' Grant began working on this argument in a paper, 'Christianity and the Modern Multiversity,' delivered at Trinity College, University of Toronto in 1977.

78 'La foi, c'est l'expérience que l'intelligence est éclairée par l'amour.' Simone Weil, La Pesanteur et la Grâce (Paris: Plon 1948), 148

79 Ibid., 76 See the discussion in William Christian, George Grant: A Biography (Toronto: University of Toronto Press 1993), 353-60

80 Ibid., 76

81 George Grant, 'Notebook: Zarathustra,' [1969] 


\section{Editor's Introduction xli}

82 Ibid.

83 George Grant, 'Faith and the Multiversity,' 77. The alteration of 'gravedigger' to 'gravediggers' is Sheila Grant's.

84 George Grant, 'Notebook: Zarathustra.' The passage can be found in Hebrews, 10:31.

85 George Grant to Joan O'Donovan, 8 November 1985 
This page intentionally left blank 